\title{
Modeling of Ni Diffusion Induced Austenite Formation in Ferritic Stainless Steel Interconnects
}

Chen, Ming; Alimadadi, Hossein; Molin, Sebastian; Zhang, L.; Ta, Na; Hendriksen, Peter Vang; Kiebach, Wolff-Ragnar; Du, Y.

Published in:

Journal of The Electrochemical Society

Link to article, DOI:

10.1149/2.1711709jes

Publication date:

2017

Document Version

Peer reviewed version

Link back to DTU Orbit

Citation (APA):

Chen, M., Alimadadi, H., Molin, S., Zhang, L., Ta, N., Hendriksen, P. V., Kiebach, W-R., \& Du, Y. (2017). Modeling of Ni Diffusion Induced Austenite Formation in Ferritic Stainless Steel Interconnects. Journal of The Electrochemical Society, 164(9), F1005-F1010. https://doi.org/10.1149/2.1711709jes

\section{General rights}

Copyright and moral rights for the publications made accessible in the public portal are retained by the authors and/or other copyright owners and it is a condition of accessing publications that users recognise and abide by the legal requirements associated with these rights.

- Users may download and print one copy of any publication from the public portal for the purpose of private study or research.

- You may not further distribute the material or use it for any profit-making activity or commercial gain

- You may freely distribute the URL identifying the publication in the public portal 
1 Modeling of Ni Diffusion Induced Austenite Formation in Ferritic Stainless Steel

2 Interconnects ${ }^{* *}$

3

4 M. Chen ${ }^{\text {a, }}{ }^{*}$, H. Alimadadi ${ }^{b}$, S. Molin ${ }^{a}$, L. Zhang ${ }^{c}$, N. Ta ${ }^{a, c}$, P. V. Hendriksen ${ }^{a}$, R.

5 Kiebach $^{\mathrm{a}}$, and Y. Du ${ }^{\mathrm{c}}$

6

$7{ }^{a}$ Department of Energy Conversion and Storage, Technical University of Denmark,

8 Roskilde 4000, Denmark

9 b Center for Electron Nanoscopy, Technical University of Denmark, Lyngby 2800,

10 Denmark

11 c State Key Laboratory of Powder Metallurgy, Innovative Materials Design Group,

12 Central South University, Changsha, Hunan 410083, China

13

$14{ }^{*}$ Corresponding author. Tel.: +45 46775757; Fax: +45 46775858; Email: minc@dtu.dk.

15

$16{ }^{* *}$ Part of this manuscript has been published previously in ECS Transactions (M. Chen, S.

17 Molin, L. Zhang, N. Ta, P. V. Hendriksen, W. R. Kiebach, and Y. Du, "Modeling of Ni

18 Diffusion Induced Austenite Formation in Ferritic Stainless Steel Interconnects”, ECS

19 Transactions, 68 [1] 1691-1700 (2015).).

20 


\section{Abstract}

23 Ferritic stainless steel interconnect plates are widely used in planar solid oxide fuel

24 cell and electrolysis cell stacks. During stack production and operation, nickel from the

$25 \mathrm{Ni} /$ yttria stabilized zirconia fuel electrode or from the Ni contact component layer 26 diffuses into the interconnect plate, causing transformation of the ferritic phase into an

27 austenitic phase in the interface region. This is accompanied with changes in volume, and

28 in mechanical and corrosion properties of the interconnect plates. In this work, kinetic

29 modeling of the inter-diffusion between $\mathrm{Ni}$ and FeCr based ferritic stainless steel was

30 conducted, using the CALPHAD (CALculation of PHAse Diagrams) approach with the

31 DICTRA (DIffusion Controlled TRAnsformation) software. The kinetics of inter-

32 diffusion and austenite formation was explored in detail. The simulation was further

33 validated by comparing with experiments. The results show that after $2000 \mathrm{~h}$ at $800{ }^{\circ} \mathrm{C} \mathrm{Ni}$

34 diffuses more than $100 \mu \mathrm{m}$ deep into Crofer 22 APU. Along with the Ni diffusion, part

35 of the ferritic steel with 50-60 $\mu \mathrm{m}$ in thickness has transformed into the austenitic phase.

36 Growth of the austenite phase in commercial interconnect materials was predicted to take

37 place under practical stack operation conditions. 


\section{Introduction}

43 Owing to their high temperature stability and relatively low cost, chromia-forming

44 ferritic stainless steels are widely used as interconnect materials in solid oxide fuel cell

45 (SOFC) and electrolysis cell (SOEC) stacks. This type of steel typically has a chromium

46 content of 20 - 30 wt.\%. The thermal expansion coefficient (TEC) matches well with that

47 of anode supported solid oxide cells (SOCs) [1]. During high temperature oxidation, a

48 chromium oxide scale forms on the steel, which has a reasonable electronic conductivity

49 at typical SOFC/SOEC operating temperature $\left(650-850{ }^{\circ} \mathrm{C}\right)$ [2]. For practical

50 applications, protective coatings are required especially for the oxygen side, to enhance

51 the oxidation resistance and the electrical conductivity of the formed oxide scale and to

52 mitigate Cr evaporation. Recent progress on alloy and coating development for ferritic

53 stainless steel interconnects has been reviewed by Shaigan et al. [3].

55 In the so-called planar stack design, a certain number of planar SOCs are stacked, 56 with shaped interconnects (ICs) in between. These plates serve as interconnects and 57 separate the neighboring fuel and oxygen electrode compartments of adjacent cells. An 58 intimate contact between the electrodes and the IC plate is essential to ensure optimum 59 cell and stack performance. During stack production and operation, inter-diffusion of 60 elements across the cell - IC interface takes place, which under certain circumstances

61 introduces adverse effects on the electrical, mechanical, and corrosion properties of the

62 IC plates, and may further damage the electrodes. One representative example is the 63 diffusion of nickel from the Ni/YSZ fuel electrode or from the Ni contact component

64 layer into the IC plate, while iron and chromium from the steel diffuse in the opposite 
65 direction. Diffusion of Ni into the steel causes transformation of the ferritic (BCC) phase

66 into the austenitic (FCC) phase in the interface region, accompanied with changes in

67 volume and in mechanical and corrosion properties of the IC plates. A number of studies

68 have been devoted to investigate this process experimentally. Sakai et al. reported a radial

69 pattern of Ni diffusion into ZMG232 [4]. Chromium depletion and internal oxidation

70 occurred in the diffusion zone. Pre-oxidation of the steel was reported to be effective in

71 suppressing the inter-diffusion, but resulted in an increase of the contact resistance.

72 Quadakkers and his co-workers investigated Ni diffusion and formation of the austenite

73 phase in both long-term tested SOFC stacks and model samples including a Ni mesh in

74 contact with Crofer 22 APU or Crofer $22 \mathrm{H}[2,5]$. In addition to austenite, formation of

75 sigma ( $\sigma$ ) phase was detected in the interface region [2]. The experiments were correlated

76 to the thermodynamics of the Fe-Cr-Ni system. Authors of the current work have

77 previously reported reduced oxidation kinetics in Ni electroplated Crofer 22 APU as

78 compared to uncoated ones [6]. This was attributed to slow diffusion kinetics of the FCC

79 phase (2 - 3 orders of magnitude slower than in BCC). Recently, Harthøj et al. studied Ni

80 diffusion from the Ni/YSZ fuel electrode into Crofer 22 APU and its influence on the

81 contact resistance across the interface [7]. It was concluded that the inter-diffusion

82 introduces microstructural instability, but also lower electrical resistance (due to

83 formation of metallic pathways). Similar studies have also been conducted by Mikkelsen

84 et al. [8], who investigated long-term oxidation behavior and electrical interface

85 resistance between $\mathrm{FeCr}$ alloy sheets and Ni/YSZ plates. Their results show that metallic

86 bridges exist through the formed oxide scale even after 1 year of operation. 
88 In this work, kinetic modeling of the inter-diffusion between $\mathrm{Ni}$ and FeCr based

89 ferritic stainless steel was conducted, using the CALPHAD (CALculation of PHAse

90 Diagrams) approach with the DICTRA (DIffusion Controlled TRAnsformation) software.

91 To give a full account of the observed experimental phenomena, the following processes

92 have to be taken into account: (i) inter-diffusion and transformation of ferrite into

93 austenite, (ii) oxide scale formation, and (iii) formation of $\sigma$ phase. The present work

94 focuses on the first process only. Here kinetic modeling of inter-diffusion and austenite

95 formation was explored in detail, as functions of temperature and time plus influence of 96 grain boundary diffusion. The simulation was further validated by comparing with 97 experimental results.

\section{Experimental and Kinetic Modeling}

101 We have previously reported on the oxidation kinetics of Ni coated Crofer 22 APU 102 (ThyssenKrupp VDM, Germany) in humidified $\mathrm{H}_{2} / \mathrm{N}_{2}$ [6]. The samples consisted of 300 $103 \mu \mathrm{m}$ thick Crofer 22 APU flat sheets electroplated with pure Ni on both sides. Crofer 22

104 APU contains typically 20-24 wt.\% Cr, 0.3-0.8 wt.\% Mn with some minor elements (La, $105 \mathrm{Ti}$ ) and Fe as a balance. For an exhaustive list of the chemical composition, the readers 106 are referred to our previous study [1]. The oxidation study was carried out at $800{ }^{\circ} \mathrm{C}$ in a 107 mixture of $4 \% \mathrm{H}_{2} \mathrm{O}+9 \% \mathrm{H}_{2}+87 \% \mathrm{~N}_{2}$ for periods up to 2000 hours. Detail on the 108 oxidation kinetics and microstructural evolution is presented elsewhere [6]. The 109 microstructure of one specific sample, namely the $13 \mu$ m thick Ni coated Crofer 22 APU 110 oxidized for $2000 \mathrm{~h}$, was further investigated in the present work and the post-test results 111 were employed to validate the modeling results. Polished cross-sections were first 
112 examined using a Supra 35 scanning electron microscope equipped with a field emission

113 gun (FE-SEM, Carl Zeiss). Chemical compositions were obtained via an X-ray Energy

114 Dispersive Spectrometer (EDS) with data analysis using a microanalysis software NSS

115 (Thermo Fischer Scientific Inc.). In addition, backscatter electron imaging was carried

116 out in a FEI Helios NanoLab ${ }^{\mathrm{TM}} 600$ dual beam microscope equipped with a field-

117 emission gun using accelerating voltage of $20 \mathrm{kV}$ and probe current of $1.4 \mathrm{nA}$. For phase

118 differentiation, electron backscatter diffraction (EBSD) was performed in a FEI Nova

119 NANOSEM 600 equipped with a field-emission gun. The FEI Nova NANOSEM 600

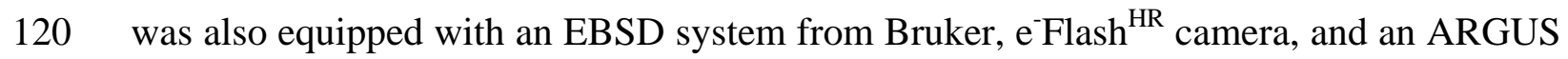

121 electron imaging system (all Bruker Nano GmbH, Berlin, Germany). The EBSD

122 measurement was performed in a square grid with an electron probe current of $3.1 \mathrm{nA}$ at

123 an acceleration voltage of $20 \mathrm{kV}$, and camera exposure time of $7 \mathrm{~ms}$. EBSD data analysis

124 was carried out using Esprit 2.0.

125

126 The modeling part was carried out using the CALPHAD approach with the Thermo-

127 Calc and DICTRA software [9]. Thermo-Calc is a powerful tool for phase equilibrium,

128 phase diagram and phase transformation calculations, whereas DICTRA is a software

129 package for simulation of diffusional reactions in multicomponent alloys. For further

130 detail on Thermo-Calc and DICTRA, the readers are referred to the paper by Andersson

131 et al. [9] and Borgenstam et al. [10]. In this work, the thermodynamics and phase

132 relations of relevant systems were explored using Thermo-Calc and TCFE7 database. For

133 kinetic modeling, a 1D diffusion couple was set up (shown in Figure 1), where metallic

134 Ni coating (FCC, denoted by Phase $\gamma$ in the current work) is in contact with FeCr-based

135 ferritic stainless steel (BCC, Phase $\alpha$ ). The inter-diffusion across the interface and the 
136 transformation of ferrite into austenite was modelled using DICTRA in conjunction with

137 both TCFE7 and MOBFE2 databases.

138

139 Results and Discussion

140

141 Model Experiment of Ni Diffusion into Crofer 22 APU

142

143 Figure 2a presents a backscatter electron (BSE) image on the polished cross-section

144 of $13 \mu \mathrm{m}$ Ni coated Crofer 22 APU after $2000 \mathrm{~h}$ oxidation at $800{ }^{\circ} \mathrm{C}$. The contrast in the

145 micrograph stems from the difference in chemical compositions and crystallographic

146 orientation. As reported previously [6], the $\mathrm{Ni}$ coating remains metallic after

147 electroplating. After 2000 h oxidation, most of the Ni has diffused into the steel. A small

148 number of Ni particles remains on the surface of the formed oxide scale. The oxide scale

149 has a thickness of about $2 \mu \mathrm{m}$ and has some metallic particles (Ni/Fe rich) as inclusions.

150 At about 60-70 $\mu \mathrm{m}$ from the oxide scale an abrupt change in contrast can be easily seen

151 in Figure 2a indicating either crystallographic orientation and/or chemical compositional

152 change. The EDS elemental mapping of the scanned area is shown in Figure 2b. The

153 oxide scale consists of mainly $\mathrm{Cr}$ and $\mathrm{Mn}$, corresponding most likely to an outer layer of

$154(\mathrm{Cr}, \mathrm{Mn})_{3} \mathrm{O}_{4}$ spinel and an inner layer of $\mathrm{Cr}_{2} \mathrm{O}_{3}$, as reported previously [6]. In the bulk of

155 the steel, the contrast difference observed in Figure 2a is reflected as change of $\mathrm{Cr} / \mathrm{Ni} / \mathrm{Fe}$

156 concentrations as shown in Figure 2b. No secondary phase (e.g. $\sigma$ phase) seems to appear 157 in the examined area.

158 
159 Based on the obtained area spectra imaging data, an integrated EDS line-scan was

160 made. The line was drawn perpendicular to the oxide scale - steel interface. Data over the

161 entire area were then integrated along the line. Figure 2c plots the atomic percentages of

$162 \mathrm{Fe}, \mathrm{Cr}, \mathrm{Ni}, \mathrm{Mn}$ from the oxide scale - steel interface into the steel, while the other

163 elements are excluded. As expected, significant inter-diffusion took place after $2000 \mathrm{~h}$ at

$164800{ }^{\circ} \mathrm{C}$. The Ni content is above 1.5 at.\% at a distance of $\sim 95 \mu \mathrm{m}$ from the oxide scale -

165 steel interface, indicating $\mathrm{Ni}$ diffuses deeper than the area investigated in the EDS

166 measurement. There seems to be a relatively sharp increase in the Cr content and a

167 decrease in the $\mathrm{Ni}$ content at the distance of $65 \mu \mathrm{m}$, in accordance with the contrast 168 change shown in Figure 2a.

170 The sample was further examined using FEI Helios NanoLab ${ }^{\mathrm{TM}} 600$ and FEI Nova

171 NANOSEM 600 to obtain information on the phases and microstructure of different

172 layers. As shown in Figure 3a, starting just beneath the oxide scale to the bulk of the steel, 1734 distinct layers with different grain structure and orientations are clearly visible. The

174 layer just beneath the oxide scale (hereafter named as Layer 1) has a thickness of $\sim 10 \mu \mathrm{m}$ 175 and a grain size of $3-5 \mu \mathrm{m}$. Layer 2 has a thickness of around 25-35 $\mu \mathrm{m}$ and consists of 176 much bigger grains, with a grain size of $8-10 \mu \mathrm{m}$. Layer 3 has a thickness of about 30 $177 \mu \mathrm{m}$ and the finest grain structure among all the 4 layers. Layer 4, located at the bottom of 178 Figure 3a, has much coarser grains, pancake-like which are elongated parallel to the steel 179 sheet. The grains are 60-80 $\mu \mathrm{m}$ in width and 300-400 $\mu \mathrm{m}$ in length. By comparing Figure 180 3a with Figure 2, it becomes evident that the boundary between Layer 3 and Layer 4 181 corresponds to the contrast change shown in Figure 2a and the sharp change of $\mathrm{Cr} / \mathrm{Ni}$ 182 content in Figure 2c. Besides, it is worth noting that the boundaries between the oxide 
183 scale and Layer 1 and between Layer 1 and layer 2 are quite parallel to the sample

184 surface, while the ones between Layer 2 and layer 3 and between Layer 3 and Layer 4 are

185 a bit wavy.

186

187 Figure 4a shows the electron backscatter pattern quality (EBSP-Q) map of an area

188 measured by EBSD. EBSP-Q maps have been extensively used for revealing grain

189 boundaries and local strain in various steels [11]. There is strong resemblance between

190 Figure 4a and Figure 3a, indicating that the area investigated by EBSD is representative

191 of the material system and all four layers are covered. In Figure 4b the phase color-coded

192 map (ferrite: green and austenite: red) is overlaid on the EBSP-Q map (Figure 4a). It is

193 evident that the majority of grains in Layers 1 and 2 are indexed as FCC austenite while

194 those in Layers 3 and 4 are mainly indexed as BCC ferrite. Even though Layer 3 is

195 mainly indexed as BCC ferrite, the microstructure features resemble those of martensite

196 [12]. Martensite has a crystal structure of body centered tetragonal (BCT), and the

197 tetragonality (c/a ratio) is dependent on the carbon content [13]. Since c/a ratio is for

198 most cases close to unity, EBSD cannot differentiate between BCC ferrite and BCT

199 martensite.

200

201 As discussed earlier, the abrupt change in $\mathrm{Cr} / \mathrm{Ni}$ content happens at the boundary

202 between Layer 3 and Layer 4, while the chemical compositions of Layers 2 and 3 are

203 comparable. Additionally, martensite forms as a result of solid state phase transformation

204 of austenite upon cooling. Hence, Layer 3 must have formed as the sample was cooling

205 down from $800^{\circ} \mathrm{C}$. Reconstructing the pre-austenite grains from EBSD data can be done

206 assuming specific orientation relations between the austenite and martensite [14]. 
207 However, using backscatter electron images it is also possible, though subjectively [7], to

208 reconstruct the pre-austenite grains. Color orientation contrast imaging using backscatter

209 electrons [15] are especially helpful for pre-austenite grain boundary reconstruction, as

210 shown in Figure 5. The reconstructed pre-austenite grains of Layer 3 (Figure 5b) show

211 that the grain sizes of the two mentioned layers (2 and 3) are comparable. Hence, one can

212 conclude that Layers 2 and 3 at elevated temperature are actually of the same phase

213 (austenite) but with different chemical compositions (see Figure 2). However, upon

214 cooling down to room temperature Layer 3 forms due to a martensitic phase

215 transformation whereas Layer 2 remains austenitic. One may see this as a discrepancy,

216 but there are two differences between layers 2 and 3 which influence the thermodynamics

217 and kinetics of solid state phase transformation: (i) Layer 2 has higher nickel content and

$218 \mathrm{Ni}$ is a well-known austenite stabilizer (see the discussion of Phase diagrams below). (ii)

219 There is a very large interface between the Layer 3 and Layer 4 (BCC ferrite). The BCC

220 ferrite is an excellent site for martensite nucleation based on the martensite heterogeneous

221 nucleation mechanism [16]. There is an autocatalytic behavior associated with the

222 martensitic phase transformation, i.e. upon nucleation and formation of martensite, new

223 sites for nucleation develop [16]. Thus, Layers 2 and 3 which seemingly cannot be

224 distinguished at elevated temperature are differentiated at room temperature by the

225 difference in thermodynamics and kinetics of phase transformation to martensite.

226

227 Phase Diagrams of Fe-Cr-Ni

228

229 As shown in Figure 2, a thin layer of oxide scale formed on each side of the Ni coated

230 steel sample. As compared to the $300 \mu \mathrm{m}$ thick steel, the oxide scale has a thickness of 
231 only $4 \mu \mathrm{m}$ (i.e. $2 \mu \mathrm{m}$ on both sides) and is therefore expected to have a minor influence

232 on the steel bulk composition. If the oxide scale were formed in advance, it would act as

233 a diffusion barrier layer between $\mathrm{Ni}$ and the steel. Considering the fact that in the current

234 study most of the coated Ni has diffused into the steel, the formation of the continuous

235 oxide scale should then occur after transformation of the original $\mathrm{Ni}$ coating into a

236 NiFeCr austenite solid solution (i.e. Layer 1 in Figure 3). As the oxide layer forms on top

237 of Layer 1, it should have minor influence on the interdiffusion process between $\mathrm{Ni}$ and

238 FeCr steel, i.e. the interdiffusion process taking place inside Layers 1-4. Formation of

239 oxide scale may however have an influence on the local chemistry at the oxide scale -

$240 \mathrm{Ni} /$ Steel interface. This will be considered in future work, when all the 3 processes (inter-

241 diffusion and formation of austenite, oxidation, and formation of $\sigma$ phase) will be

242 modelled together. In the present work, the inter-diffusion and transformation of ferrite

243 into austenite across the $\mathrm{Ni}$ - Steel interface is modelled. Figure 6 presents the phase

244 diagram of Fe-Cr-Ni calculated at two different temperatures. At $800{ }^{\circ} \mathrm{C}$, the $\alpha$ phase has

245 rather limited $\mathrm{Ni}$ solubility, while the $\gamma$ phase, originating from pure $\mathrm{Ni}$, has a wide

246 solubility range for both Fe and Cr. The single-phase region of $\sigma$ starts from the Fe-Cr

247 binary and extends into the ternary, towards the Cr-rich corner. At $900{ }^{\circ} \mathrm{C}$, the $\sigma$ single-

248 phase region exists only in the ternary system. The $700{ }^{\circ} \mathrm{C}$ phase diagram (not shown

249 here) is similar to the one at $800{ }^{\circ} \mathrm{C}$, except that the solubility of $\mathrm{Ni}$ in the $\alpha$ phase is

250 slightly higher.

251

252 Modeling of Ni Diffusion into $\mathrm{Fe}_{0.76} \underline{\mathrm{Cr}}_{0.24}$ (Bulk Diffusion only) 
254 As shown in Figure 1, a diffusion couple of $\mathrm{Ni}$ - Steel was set up which mimics the 255 experiments. As the experimental sample (Crofer 22 APU metal sheet, $300 \mu \mathrm{m}$ in 256 thickness) was coated with $\mathrm{Ni}$ on both sides, due to the existing symmetry only half of 257 the sample was modelled. Crofer 22 APU has about 20 - 24 wt.\% Cr, $0.3-0.8$ wt.\% Mn

258 plus some minor elements ( $\mathrm{La}, \mathrm{Ti}$, etc.) and Fe as a balance $[1,2,6]$. In the current work, 259 modeling was carried out on a diffusion couple of $13 \mu \mathrm{m} \mathrm{Ni}-150 \mu \mathrm{m} \mathrm{Fe}_{0.76} \mathrm{Cr}_{0.24}$ (i.e.

$260 \mathrm{Fe} / \mathrm{Cr}=76 / 24$ in atomic ratio and 77/23 in mass ratio). At first, only bulk diffusion is 261 considered. The composition profiles along the diffusion couple at different time steps 262 are presented in Figure 7 for the time periods up to $2000 \mathrm{~h}$ at $800{ }^{\circ} \mathrm{C}$. As expected, $\mathrm{Ni}$ 263 diffuses into the steel while $\mathrm{Fe}$ and $\mathrm{Cr}$ diffuse in the opposite direction. In agreement with 264 the thermodynamics (Figure 6), the content of $\mathrm{Ni}$ in the $\alpha$ phase (the right part of 265 diffusion couple) is rather low all the way from the interface to the right boundary, while 266 the contents of $\mathrm{Fe}$ and $\mathrm{Cr}$ in the $\gamma$ phase decrease continuously with the distance from the 267 interface.

269 Based on the composition profiles, the Ni diffusion distance can then be evaluated as 270 the distance from the original $\gamma / \alpha$ interface at Time $=0 \mathrm{~h}$ (i.e. Distance $=13 \mu \mathrm{m}$ in Figure 271 1) to the point where the Ni content in the $\gamma$ phase reaches below $0.5 \mathrm{wt} . \%$. The results 272 are plotted in Figure 8a for 700,800 , and $900{ }^{\circ} \mathrm{C}$. At $800{ }^{\circ} \mathrm{C}$, a Ni diffusion distance of $27371.6 \mu \mathrm{m}$ is obtained from DICTRA modeling, where only bulk diffusion is considered. 274 Accompanied with inter-diffusion, the $\gamma / \alpha$ interface moves towards right. Figure $8 \mathrm{~b}$ 275 shows the thickness of the $\gamma$ layer as a function of time at $700-900{ }^{\circ} \mathrm{C}$. At $800{ }^{\circ} \mathrm{C}$, the $\gamma$ 276 layer thickness increased from $13 \mu \mathrm{m}$ at Time $=0 \mathrm{~h}$ (i.e. the Ni coating thickness) to 19 $277 \mu \mathrm{m}$ at Time $=2000 \mathrm{~h}$. According to the experimental results, the Ni diffusion distance in 
278 Crofer 22 APU is beyond $100 \mu \mathrm{m}$ for $2000 \mathrm{~h}$ diffusion at $800{ }^{\circ} \mathrm{C}$. As shown in Figure 8b,

279 the experimentally measured $\gamma$ layer thickness is about $60-70 \mu \mathrm{m}$ (i.e. the distance from

280 the oxide scale/metal interface to the boundary between Layer 3 and Layer 4 in Figure 3),

281 much thicker than the value predicted from the simulation. DICTRA modeling seems to

282 under-estimate the inter-diffusion and hence also the accompanied $\alpha \rightarrow \gamma$ phase

283 transformation, when only bulk diffusion is considered.

$286 \quad$ Figure 9 plots the intrinsic diffusion coefficients of $\mathrm{Cr}$, Ni and Fe in the $\alpha$ (BCC) and

$287 \gamma$ (FCC) phases along the diffusion couple length at Time $=2000 \mathrm{~h}$. There is an obvious

288 difference in the component diffusion rates in the two phases. All of the components

289 diffuse much faster in the $\alpha$ phase than in $\gamma$. The difference is about two orders of

290 magnitude. Fe appears to be the fatest diffusion component in the $\alpha$ phase, followed by

$291 \mathrm{Cr}$ and $\mathrm{Ni}$. In the $\gamma$ phase, the difference in the diffusion rates of the three elements is

292 relatively smaller and $\mathrm{Cr}$ appears to be the fastest one. Transformation of $\alpha$ into $\gamma$

293 significantly slows down the $\mathrm{Cr} / \mathrm{Fe}$ outward diffusion. This explains well the reduced

294 oxidation kinetics in Ni electroplated Crofer 22 APU as compared to uncoated ones [6]. It

295 can be futher concluded that the Ni inward diffusion (especially the one in the $\gamma$ phase) is

296 the rate-limiting step for the $\alpha-\gamma$ transformation.

298 Modeling of Ni Diffusion into $\mathrm{Fe}_{0.76} \underline{\mathrm{Cr}}_{0.24}$ (Bulk + Grain Boundary Diffusion)

300 To properly account the experimental data, grain boundary diffusion should also be 301 considered. Grain boundary diffusion is important and often non-negligible contributor to 
302 the total diffusion, especially at low temperatures. The grain boundary diffusion model in

303 DICTRA was next employed [10] to the case at hand. The grain boundary diffusion is

304 correlated to the bulk diffusion by using the same frequency factor, but a modified bulk

305 activation energy, as specified by the equation below:

306

$307 \quad \mathrm{M}^{\mathrm{gb}}=\mathrm{M}_{0}^{\text {bulk }} \cdot \exp \left(\mathrm{F}_{\text {redGB }} \cdot \mathrm{Q}^{\text {bulk }} / \mathrm{R} / \mathrm{T}\right)$

308

309 where $\mathrm{M}^{\mathrm{gb}}$ is the mobility in the grain boundary, $\mathrm{M}_{0}^{\text {bulk }}$ and $\mathrm{Q}^{\text {bulk }}$ are the frequency-factor

310 and activation energy in the bulk, respectively, and $\mathrm{F}_{\text {redGB }}$ is the bulk diffusion activation

311 energy multiplier. The total mobility including both bulk and grain boundary diffusion is

312 then formulated as:

313

$314 \quad \mathrm{M}^{\text {Total }}=\delta / \mathrm{d} \cdot \mathrm{M}^{\mathrm{gb}}+(1-\delta / \mathrm{d}) \cdot \mathrm{M}^{\mathrm{bulk}}$

316 where $\delta, d$, and $M^{\text {bulk }}$ are the grain boundary thickness, the grain size as a function of

317 time and temperature, and the mobility in the bulk, respectively. The grain boundary

318 diffusion model in DICTRA requires three input parameters: $\mathrm{F}_{\text {redGB }}, \delta$ and $\mathrm{d}$. In the

319 current work, grain boundary diffusion is considered for both the $\alpha$ and $\gamma$ phases. Here

320 the grain size was assumed to be constant with time, which reduces the complexity of

321 system without sacrificing the accuracy of predictions of the model. A grain size of 50

322 and $5 \mu \mathrm{m}$ was adopted for the $\alpha$ and $\gamma$ phases, respectively, according to the results

323 reported by Garcia-Fresnillo et al. [2]. This is also in qualitative agreement with the grain

324 size shown in Figure 3, even though there the sample has been heat treated at $800{ }^{\circ} \mathrm{C}$ for

$3252000 \mathrm{~h}$. The grain size of electroplated $\mathrm{Ni}$ is in submicron range, and after 30 minutes at 
326 elevated temperature the grain growth changes minimally with temperature [17]. Hence,

327 when long time treatment is considered, the grain growth of $\mathrm{Ni}$ at the very early stage can

328 be neglected. The grain boundary thickness $\delta$ was set as $0.5 \cdot 10^{-10} \mathrm{~m}$, as recommended by

329 DICTRA. The bulk diffusion activation energy multiplier $\mathrm{F}_{\text {redGB }}$ was varied between 0.5

330 and 0.7. The best fit to the experimental data (shown in Figure 10a) was achieved at

$331 \quad \mathrm{~F}_{\text {redGB }}=0.65$ for both $\alpha$ and $\gamma$ phases. Figure 10a presents the simulated composition

332 profile in comparison with the experimental results obtained from the present work

333 (Figures 2-4). As shown in Figures 2-4, after $2000 \mathrm{~h}$ at $800{ }^{\circ} \mathrm{C}$, most of the $\mathrm{Ni}$ has

334 diffused into the steel and the original $\mathrm{Ni}$ - steel interface is replaced by the oxide scale -

335 steel interface. This point was then set as "distance zero" as for the experimental data

336 points. As shown in Figure 10a, with the chosen parameters, the DICTRA modeling

337 results are in reasonable agreement with the experimental ones. The $\gamma$ phase layer has

338 grown to $63 \mu \mathrm{m}$ in thickness (including the initial $13 \mu \mathrm{m} \mathrm{Ni} \mathrm{coating).} \mathrm{By} \mathrm{plotting} \mathrm{the}$

339 composition profile onto the ternary phase diagram, the diffusion path at different time

340 steps can be illustrated. This is shown in Figure 10b. Four time steps are included: $1 \mathrm{~h}$,

$341100 \mathrm{~h}, 1000 \mathrm{~h}$, and $2000 \mathrm{~h}$. At time $=1 \mathrm{~h}$, the diffusion path starts from pure $\mathrm{Ni}$ and

342 travels through the $\gamma$ single-phase region all the way to the $\alpha+\gamma$ two-phase region and

343 ends at the composition $\mathrm{Fe}_{0.76} \mathrm{Cr}_{0.24}$. The change to the diffusion path with time happens

344 mainly in the $\gamma$ single-phase region, which is due to its wide composition range and

345 slower diffusion kinetics (two orders of magnitude slower than that of the $\alpha$ phase). The

346 diffusion path in the $\alpha+\gamma$ two-phase region moves slowly towards the $\alpha+\gamma+\sigma$ three-phase

347 triangle. Thermodynamic calculations suggest that the equilibrium state of the given

348 system $\left(13 \mu \mathrm{m}\right.$ thick $\mathrm{Ni}+150 \mu$ m thick $\left.\mathrm{Fe}_{0.76} \mathrm{Cr}_{0.24}\right)$ is a $\gamma+\sigma$ two-phase mixture.

349 Continuing after $2000 \mathrm{~h}$, the diffusion path will travel through the $\alpha+\gamma+\sigma$ three-phase 
350 triangle and end in the $\gamma+\sigma$ two-phase region eventually. To successfully model the entire

351 process, diffusion in multi-phase mixtures should be properly accounted for. This will be

352 presented in the future.

353

$354 \quad$ Figure 11 plots the predicted thickness of the $\gamma$ layer in the diffusion couple of $\mathrm{Ni}-$ $355 \mathrm{Fe}_{0.76} \mathrm{Cr}_{0.24}$ heat treated at $800{ }^{\circ} \mathrm{C}$ for periods up to $2000 \mathrm{~h}$. For comparison, the 356 experimentally measured values are also included. These values were obtained by

357 measuring the thickness of the three layers (Layers $1+2+3$ in Figure 3a) from the SEM

358 backscatter images at 20-30 different locations. As mentioned before, the boundary

359 between Layer 3 and Layer 4 is quite wavy, which gives a quite large scatter in the

360 experimentally measured $\gamma$ layer thickness. But still, the DICTRA simulations agree

361 reasonably well with the experimental values, also for the sample heat treated for only

$3621000 \mathrm{~h}$, where the experimental results were not taken into account when adjusting 363 parameters for the grain boundary diffusion.

\section{Conclusions}

367 In the current work, the inter-diffusion between $\mathrm{Ni}$ and ferritic steel interconnects was 368 investigated by means of both experiments and theoretical diffusion modeling employing 369 the DICTRA software in conjunction with both thermodynamic and diffusion databases.

370 The experimental results show that after $2000 \mathrm{~h}$ at $800{ }^{\circ} \mathrm{C}$ Ni diffuses more than $100 \mu \mathrm{m}$

371 deep into the Crofer 22 APU steel. Along with the Ni diffusion, part of the ferritic steel 372 with 50-60 $\mu \mathrm{m}$ in thickness has transformed into the austenitic phase. DICTRA modeling

373 gives a proper account of the experimental results on inter-diffusion and accompanied $\alpha$ 
$374 \rightarrow \gamma$ phase transformation, when both bulk and grain boundary diffusion are considered.

375 The Cr diffusion rate is significantly reduced with the $\alpha$-to- $\gamma$ phase transformation, 376 accounting well for the reduced oxidation kinetics of Ni electroplated samples. The

377 simulation identifies also the rate limiting step of the $\alpha$-to- $\gamma$ phase transformation, being

378 the Ni inward diffusion, especially in the $\gamma$ phase. The present work provides a proper

379 account of the thermodynamics and kinetics of Ni-steel inter-diffusion and the results

380 could be employed to further analysis of associated changes in the mechanical and

381 corrosion properties of the IC plates, which will be presented near future.

382

383 Acknowledgments

384

385 The projects ForskEL 2013-1-12013 “Solid Oxide Electrolysis for Grid Balancing” 386 funded by Energinet.dk and EUDP 64012-0225 "SOFC Accelerated - Development to 387 Accelerate Field Demonstrations" funded by Danish Energy Agency are gratefully 388 acknowledged. The A.P. Møller and Chastine Mc-Kinney Møller Foundation is gratefully 389 acknowledged for their contribution toward the establishment of the Center for Electron 390 Nanoscopy at the Technical University of Denmark.

\section{References}

393 1. M. Palcut, L. Mikkelsen, K. Neufeld, M. Chen, R. Knibbe, and P. V. Hendriksen, 394 Corros. Sci., 52, 3309 (2010).

395 2. L. Garcia-Fresnillo, V. Shemet, A. Chyrkin, L. G. J. de Haart, and W. J. Quadakkers, 396 J. Power Sources, 271, 213 (2014).

397 3. N. Shaigan, W. Qu, D. G. Ivey, and W. Chen, J. Power Scources, 195, 1529 (2010). 
398 4. N. Sakai, T. Horita, K. Yamaji, Y. P. Xiong, H. Kishimoto, M. E. Brito, and H.

399 Yokokawa, Solid State Ionics, 177, 1933 (2006).

400 5. J. Froitzheim, L. Niewolak, M. Brandner, L. Singheiser, and W. J. Quadakkers, J. Fuel

401 Cell Sci. Technol., 7, (2010).

402 6. S. Molin, M. Chen, J. R. Bowen, and P. V. Hendriksen, ECS Trans., 57, 2245 (2013).

403 7. A. Harthoj, H. Alimadadi, T. Holt, and P. Moller, J. Electrochem. Soc., 162, F387

404 (2015).

405 8. L. Mikkelsen, J. Hogh, and P. V. Hendriksen, in Proceeding of the 8th European

406 SOFC Forum, p. A0905, Lucerne, Switzerland (2008).

407 9. J.-O. Andersson, T. Helander, L. Hoglund, P. Shi, and B. Sundman, CALPHAD, 26, $408273(2002)$.

409 10. A. Borgenstam, L. Hoglund, J. Agren, and A. Engstrom, J. Phase Equilib., 21, 269

410 (2000).

411 11. S. I. Wright and M. M. Nowell, Microsc. Microanal., 12, 72 (2006).

412 12. S. Morito, H. Tanaka, R. Konishi, T. Furuhara, and T. Maki, Acta Mater., 51, 1789

413 (2003).

414 13. L. Ryde, Mater. Sci. Technol., 22, 1297 (2006).

415 14. C. Cayron, J. Appl. Crystallogr., 40, 1183 (2007).

416 15. A. P. DAY and T. E. QUESTED, J. Microscopy, 195, 186 (1999).

417 16. G. B. Olson and Z. D. Feinberg, in Woodhead Publishing Series in Metals and

418 Surface Engineering, p. 59, Woodhead Publishing, (2012).

419 17. A. J. Detor and C. A. Schuh, J. Mater. Res., 22, 3233 (2007). 


\section{Figure Captions}

421 Figure 1. Schematic illustration of the diffusion couple between Ni coating (left) and

422 FeCr-based ferritic stainless steel used for IC (right).

423

424 Figure 2. (a) Backscatter electron image and (b) EDS elemental map on the polished 425 cross-section of the oxide scale - steel (Crofer 22 APU) interface; (c) Integrated EDS 426 line-scan perpendicular to the oxide scale - steel (Crofer 22 APU) interface. The sample

427 is a $300 \mu \mathrm{m}$ thick Crofer 22 APU sheet coated with $13 \mu \mathrm{m}$ thick Ni coating on both sides, 428 further heat treated at $800{ }^{\circ} \mathrm{C}$ in $\mathrm{H}_{2}+\mathrm{N}_{2}+\mathrm{H}_{2} \mathrm{O}$ for $2000 \mathrm{~h}$.

429

430 Figure 3. (a) Backscatter electron image covering all four distinct layers in the steel. (b)

431 A higher magnification backscatter electron image of the region marked by the black 432 square in (a) showing the fine-grained microstructure of Layer 3.

434 Figure 4. (a) Electron backscatter pattern quality (EBSP-Q) map of an area covering all 435 four layers. (b) Color coded phase map (ferrite: green and austenite: red) overplayed on 436 EBSP-Q map.

438 Figure 5. (a) ARGUS ${ }^{\mathrm{TM}}$ image [15] of the Layers 2, 3 and 4. (b) A subjective 439 reconstruction of pre-austenite grains of Layer 2 and Layer 3.

441 Figure 6. Phase diagrams of Fe-Cr-Ni at 800 and $900{ }^{\circ} \mathrm{C}$. In the diagrams all the single442 phase regions have been marked: $\alpha$ - BCC (ferrite), $\gamma$ - FCC (austenite), and $\sigma$. The red 
443 triangles indicate 3-phase equilibrium $(\alpha+\gamma+\sigma)$, while the remaining unmarked regions

444 are 2-phase equilibria $(\alpha+\gamma, \gamma+\sigma$, or $\alpha+\sigma)$.

445

446 Figure 7. Calculated composition profiles (in mole fraction) along the diffusion couple of

$447 \mathrm{Ni}-\mathrm{Fe}_{0.76} \mathrm{Cr}_{0.24}$ heat treated at $800{ }^{\circ} \mathrm{C}$ for periods up to $2000 \mathrm{~h}$. The initial thickness was

$44813 \mu \mathrm{m}$ and $150 \mu \mathrm{m}$ for the $\mathrm{Ni}$ and $\mathrm{Fe}_{0.76} \mathrm{Cr}_{0.24}$ layers, respectively. Only bulk diffusion 449 was considered here.

451 Figure 8. (a) Calculated Ni diffusion distance and (b) thickness of the $\gamma$ layer in the 452 diffusion couple of $\mathrm{Ni}-\mathrm{Fe}_{0.76} \mathrm{Cr}_{0.24}$ heat treated at $700-900{ }^{\circ} \mathrm{C}$ for periods up to $2000 \mathrm{~h}$. 453 The initial thickness was $13 \mu \mathrm{m}$ and $150 \mu \mathrm{m}$ for the $\mathrm{Ni}$ and $\mathrm{Fe}_{0.76} \mathrm{Cr}_{0.24}$ layers, 454 respectively. The Ni diffusion distance is defined as the distance from the initial $\gamma / \alpha$ 455 interface at $0 \mathrm{~h}$ (i.e. Distance $=13 \mu \mathrm{m}$ in Figure 1 ) to the position where the Ni content 456 reaches below 0.5 wt.\%. Only bulk diffusion was considered here.

458 Figure 9. Intrinsic diffusion coefficients of $\mathrm{Cr}, \mathrm{Ni}$ and $\mathrm{Fe}$ in $\alpha$ and $\gamma$ phases along the 459 diffusion couple of $\mathrm{Ni}-\mathrm{Fe}_{0.76} \mathrm{Cr}_{0.24}$ heat treated at $800{ }^{\circ} \mathrm{C}$ at Time $=2000$ h. Only bulk 460 diffusion was considered here.

462 Figure 10. (a) Left: Simulated composition profiles (in mole fraction) along the diffusion 463 couple of $\mathrm{Ni}-\mathrm{Fe}_{0.76} \mathrm{Cr}_{0.24}$ heat treated at $800{ }^{\circ} \mathrm{C}$ for periods up to $2000 \mathrm{~h}$. The initial 464 thickness was $13 \mu \mathrm{m}$ and $150 \mu \mathrm{m}$ for the $\mathrm{Ni}$ and $\mathrm{Fe}_{0.76} \mathrm{Cr}_{0.24}$ layers, respectively. Both 465 bulk and grain boundary diffusion are considered. The experimental data points are from 466 the present work (Figure 2c). Mn was excluded in calculating mole fraction; (b) Right: 
467 diffusion path at $1 \mathrm{~h}$ (red), $100 \mathrm{~h}$ (green), $1000 \mathrm{~h}$ (blue), $2000 \mathrm{~h}$ (pink) super-imposed 468 onto the Fe-Cr-Ni phase diagram at $800{ }^{\circ} \mathrm{C}$.

469

470 Figure 11. Thickness of the $\gamma$ layer in the diffusion couple of $\mathrm{Ni}-\mathrm{Fe}_{0.76} \mathrm{Cr}_{0.24}$ heat treated 471 at $800{ }^{\circ} \mathrm{C}$ for periods up to $2000 \mathrm{~h}$. The initial thickness was $13 \mu \mathrm{m}$ and $150 \mu \mathrm{m}$ for the $472 \mathrm{Ni}$ and $\mathrm{Fe}_{0.76} \mathrm{Cr}_{0.24}$ layers, respectively. The experimental values were obtained from SEM 473 image analysis, where the thickness of Layers $1+2+3$ was measured at 20-30 different 474 locations.

475

476

477

478

479 
FeCr-based ferritic

Ni coating stainless IC steel

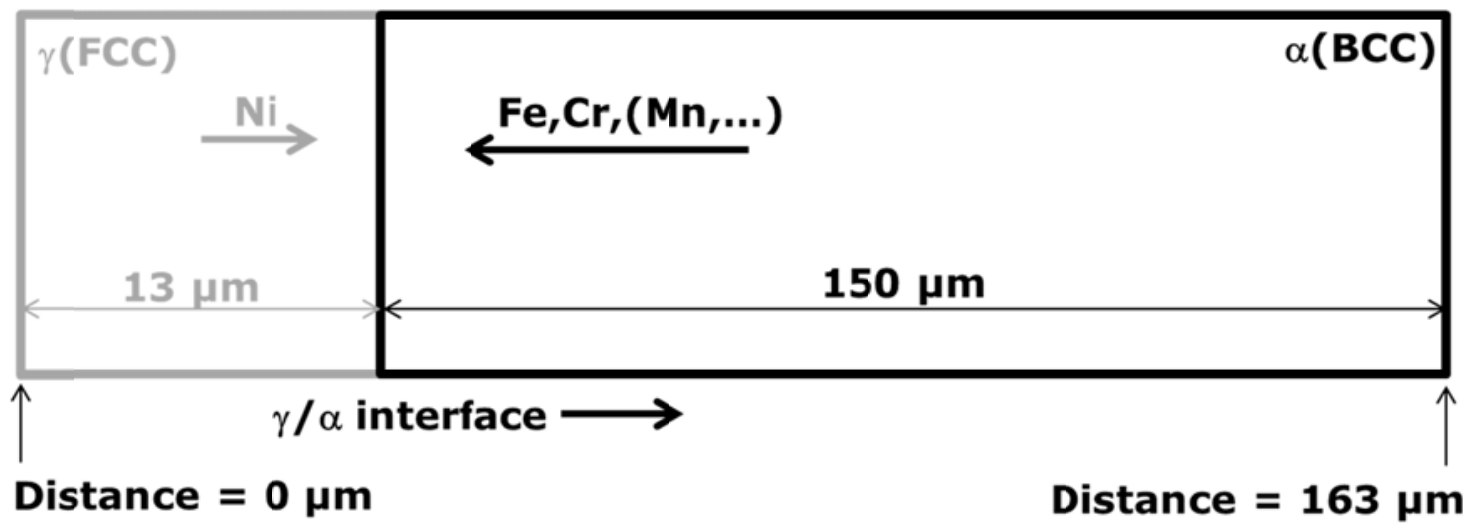

481

483 Figure 1. Schematic illustration of the diffusion couple between Ni coating (left) and

484 FeCr-based ferritic stainless steel used for IC (right).

484 

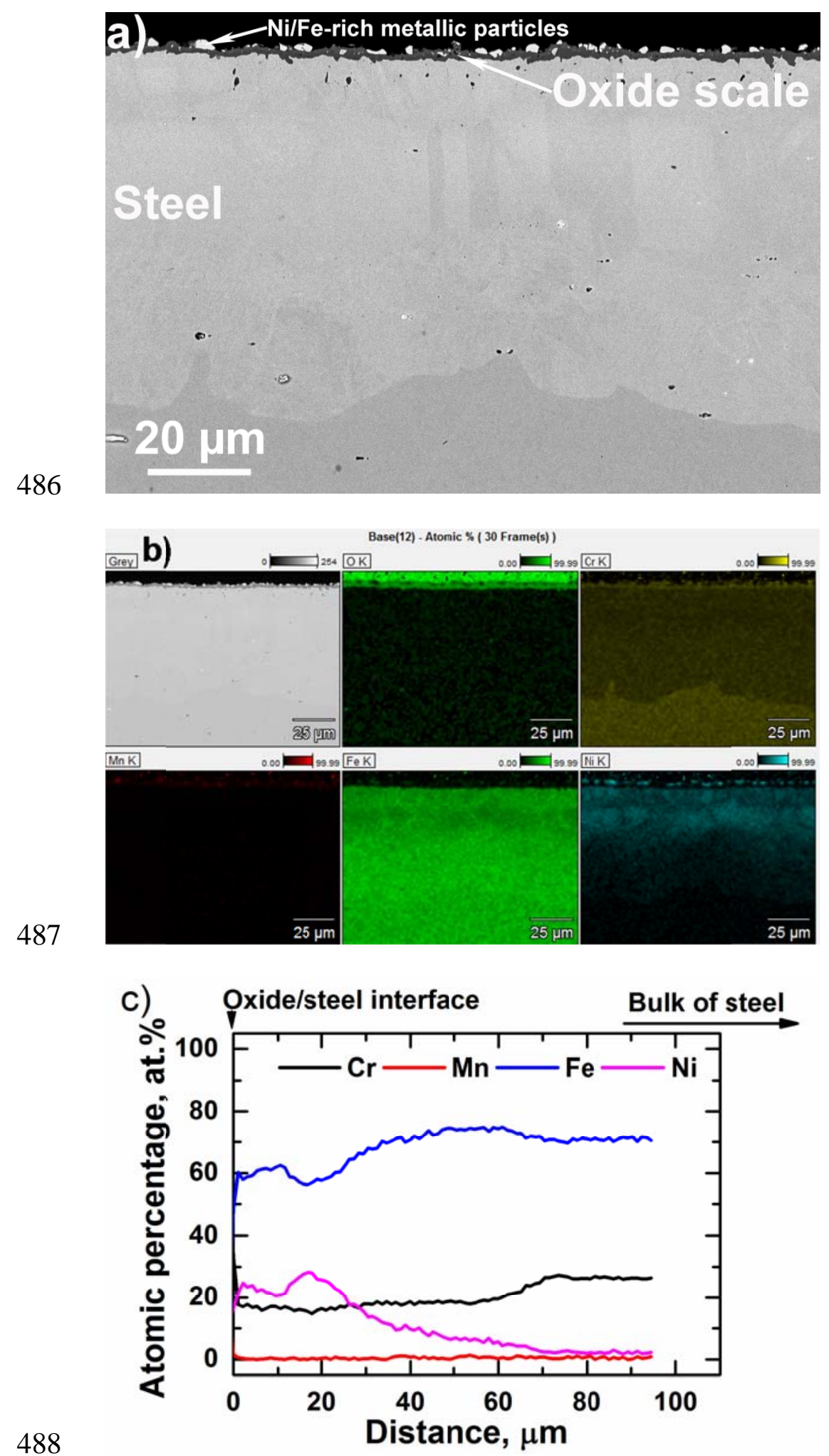

490 Figure 2. (a) Backscatter electron image and (b) EDS elemental map on the polished

491 cross-section of the oxide scale - steel (Crofer 22 APU) interface; (c) Integrated EDS 
490 line-scan perpendicular to the oxide scale - steel (Crofer 22 APU) interface. The sample 491 is a $300 \mu \mathrm{m}$ thick Crofer 22 APU sheet coated with $13 \mu \mathrm{m}$ thick Ni coating on both sides, 492 further heat treated at $800{ }^{\circ} \mathrm{C}$ in $\mathrm{H}_{2}+\mathrm{N}_{2}+\mathrm{H}_{2} \mathrm{O}$ for $2000 \mathrm{~h}$.

493 
494

495

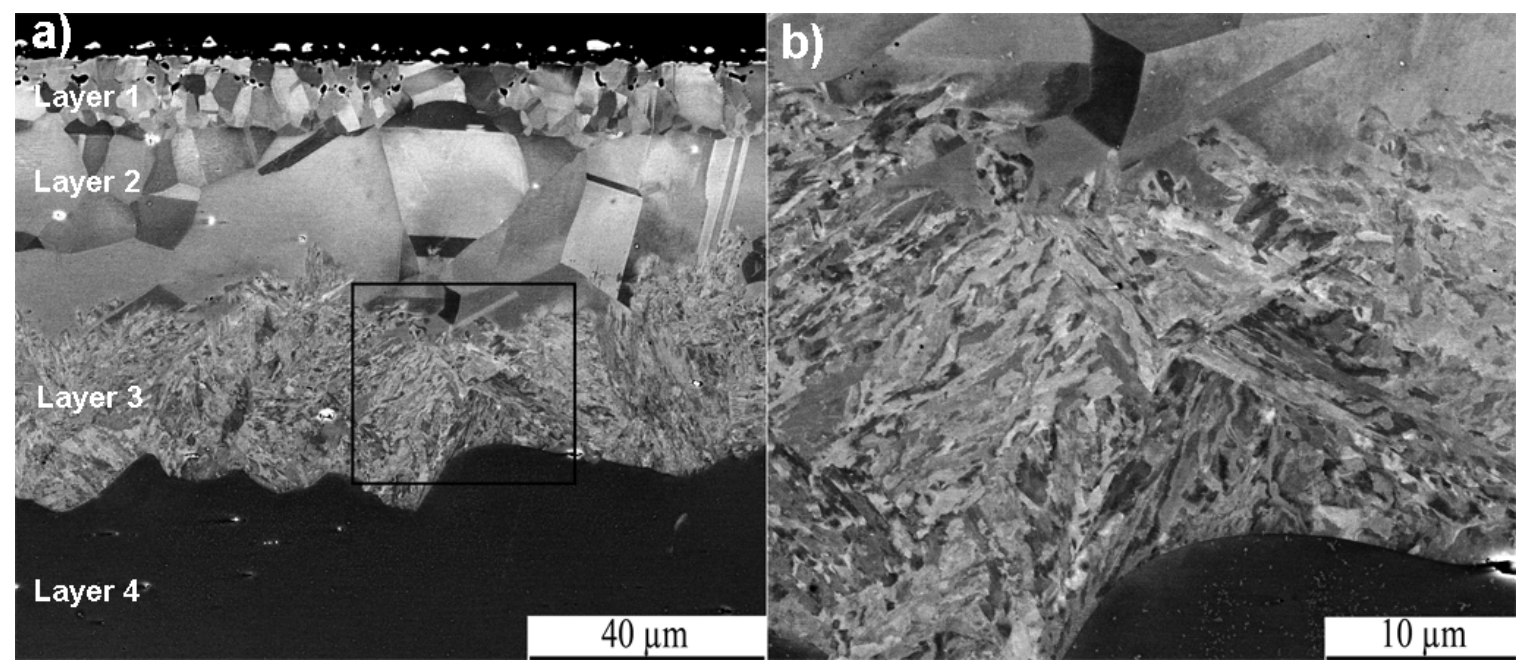

496 Figure 3. (a) Backscatter electron image covering all four distinct layers in the steel. (b)

497 A higher magnification backscatter electron image of the region marked by the black 498 square in (a) showing the fine-grained microstructure of Layer 3.

499 


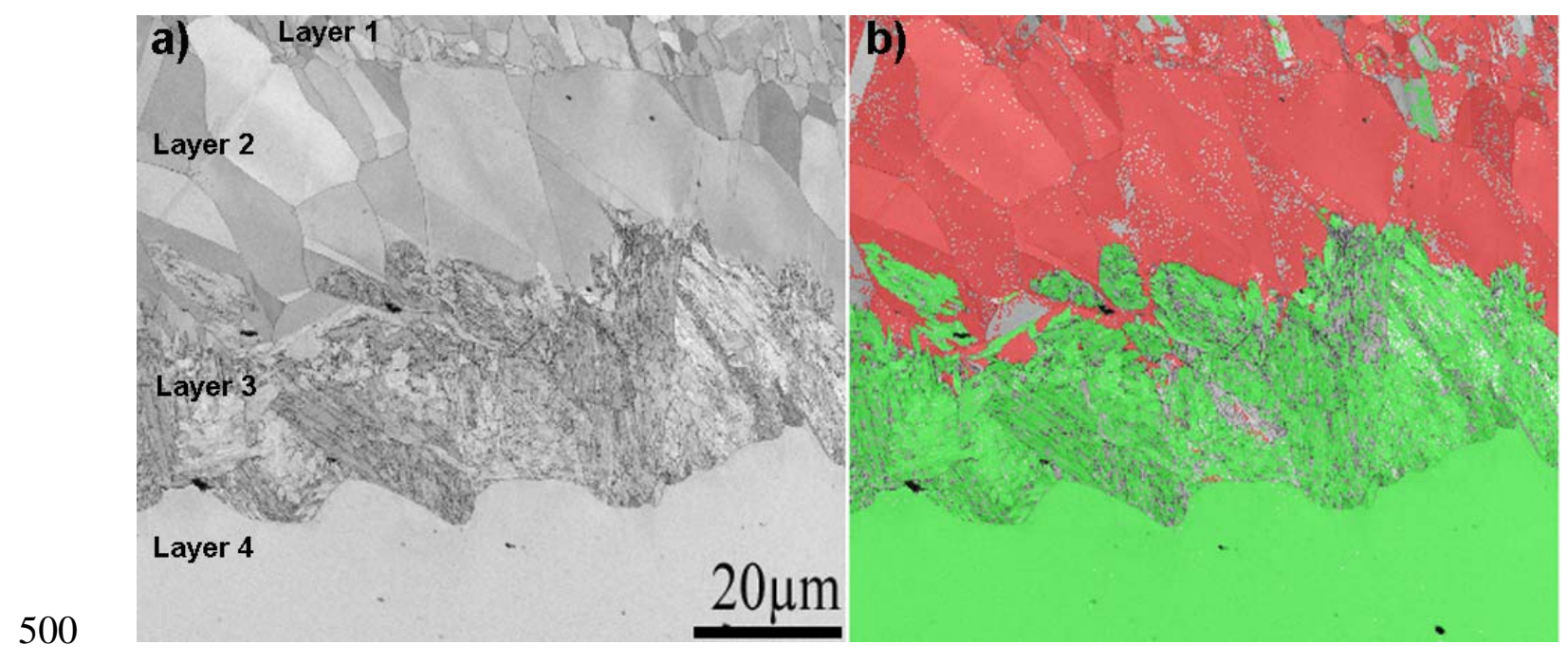

501 Figure 4. (a) Electron backscatter pattern quality (EBSP-Q) map of an area covering all

502 four layers. (b) Color coded phase map (ferrite: green and austenite: red) overplayed on 503 EBSP-Q map.

504 

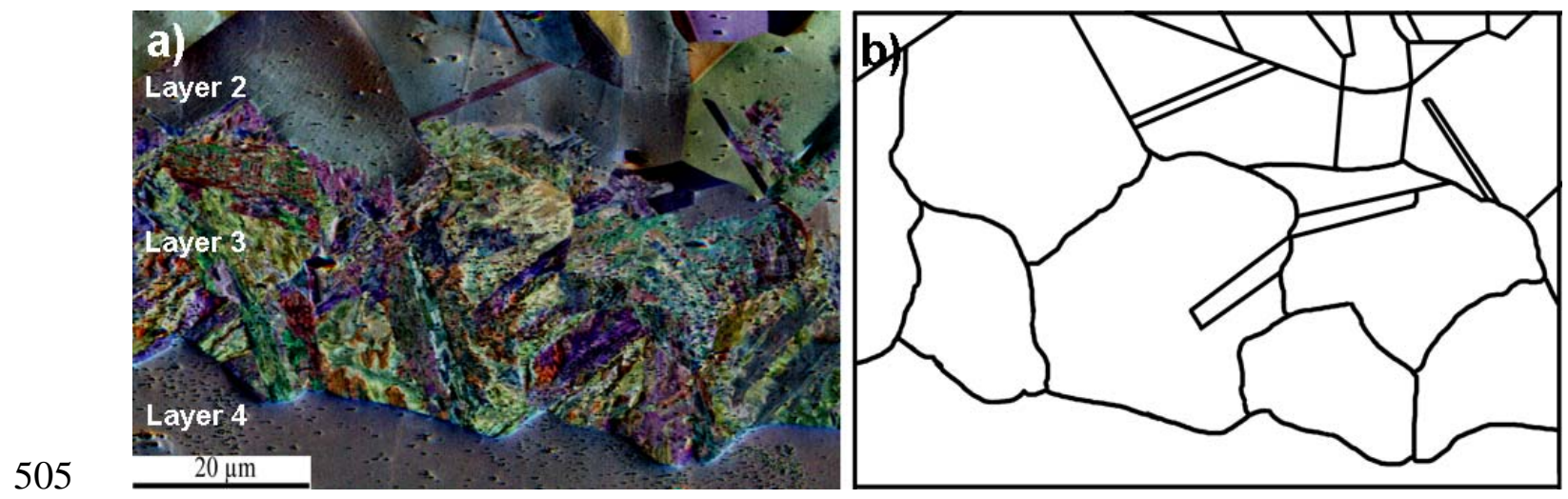

506 Figure 5. (a) ARGUS ${ }^{\mathrm{TM}}$ image [15] of the Layers 2, 3 and 4. (b) A subjective

507 reconstruction of pre-austenite grains of Layer 2 and Layer 3.

508

509 

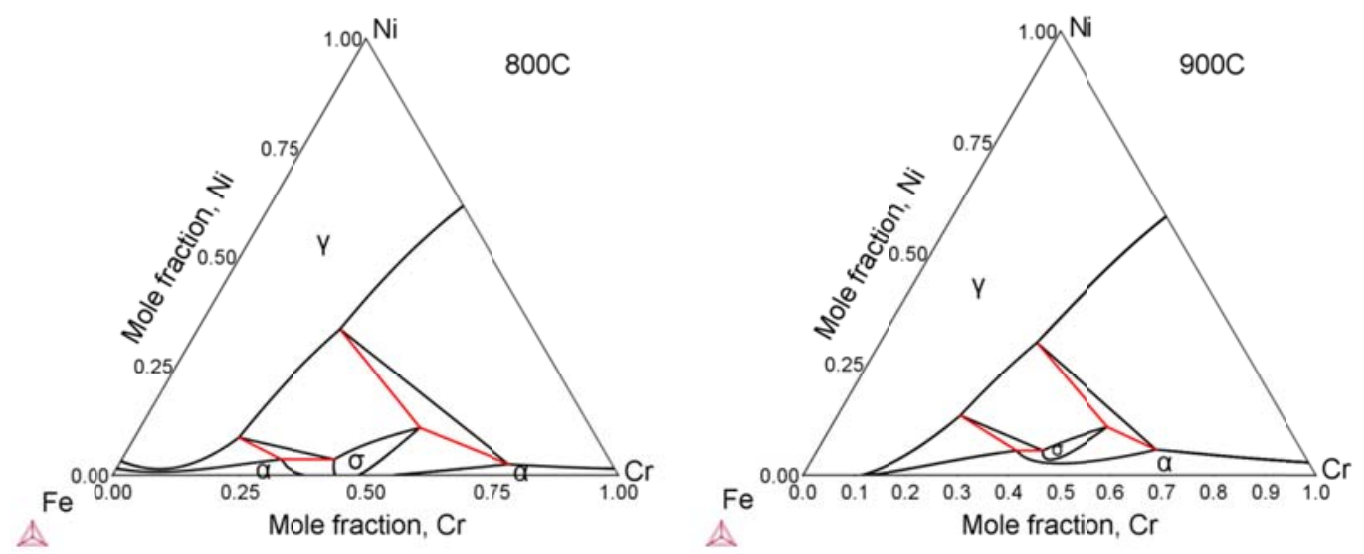

515 Figure 6. Phase diagrams of Fe-Cr-Ni at 800 and $900{ }^{\circ} \mathrm{C}$. In the diagrams all the single-

516 phase regions have been marked: $\alpha$ - BCC (ferrite), $\gamma$ - FCC (austenite), and $\sigma$. The red

517 triangles indicate 3-phase equilibrium $(\alpha+\gamma+\sigma)$, while the remaining unmarked regions

518 are 2-phase equilibria $(\alpha+\gamma, \gamma+\sigma$, or $\alpha+\sigma)$.

516

517 


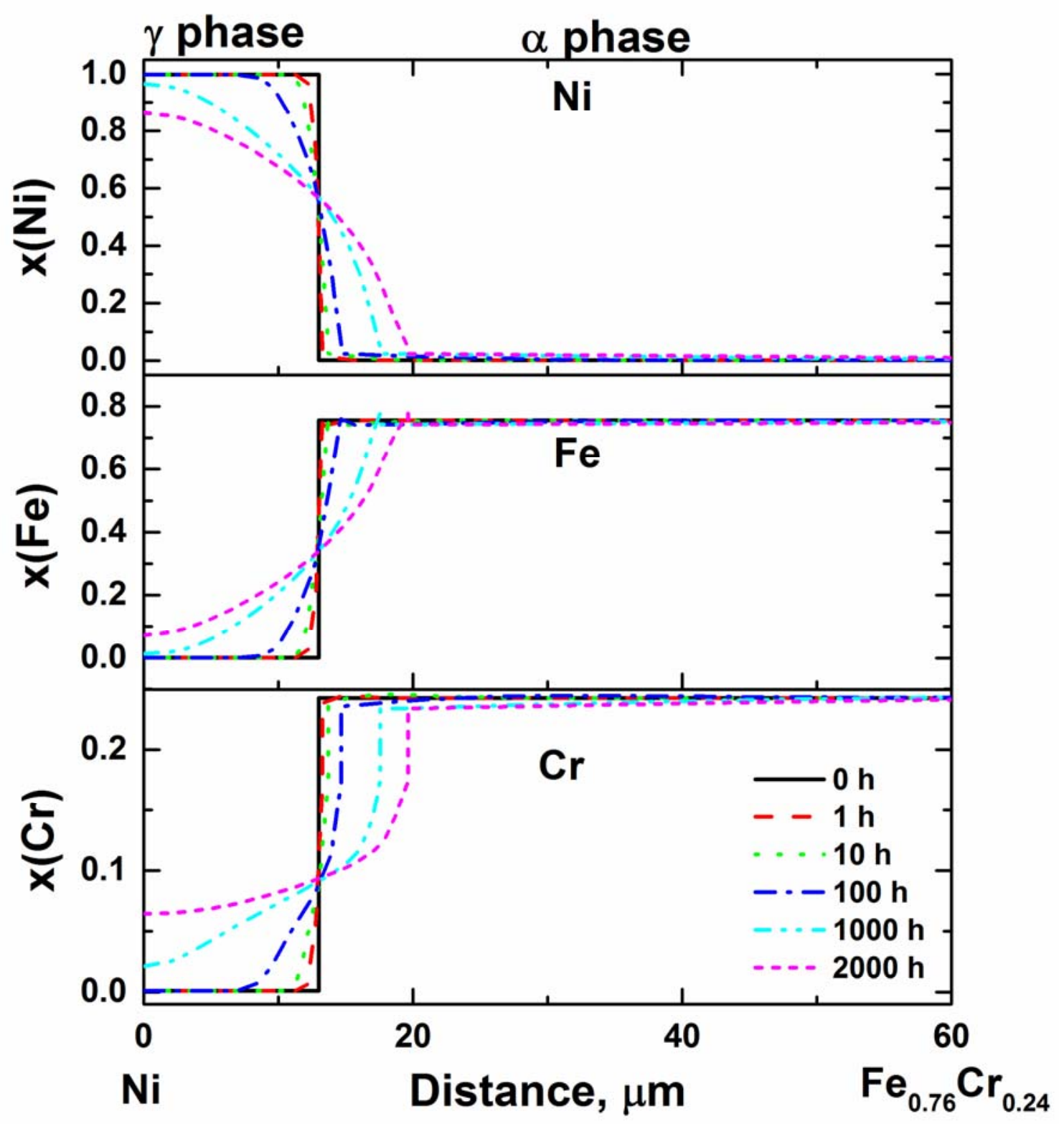

518 Figure 7. Calculated composition profiles (in mole fraction) along the diffusion couple of

$519 \mathrm{Ni}-\mathrm{Fe}_{0.76} \mathrm{Cr}_{0.24}$ heat treated at $800{ }^{\circ} \mathrm{C}$ for periods up to $2000 \mathrm{~h}$. The initial thickness was

$52013 \mu \mathrm{m}$ and $150 \mu \mathrm{m}$ for the $\mathrm{Ni}$ and $\mathrm{Fe}_{0.76} \mathrm{Cr}_{0.24}$ layers, respectively. Only bulk diffusion

521 was considered here.

522

523 
a)

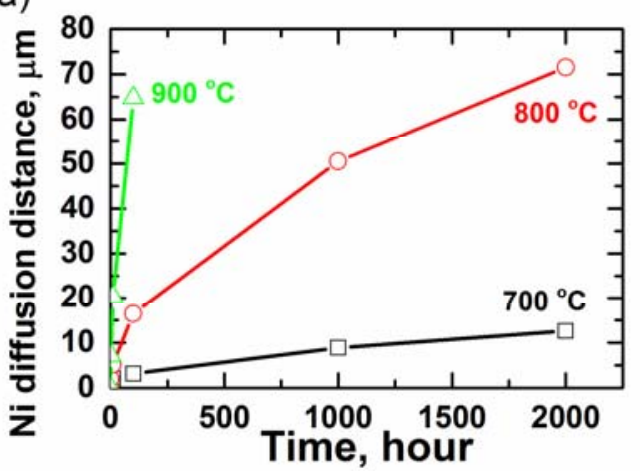

b)

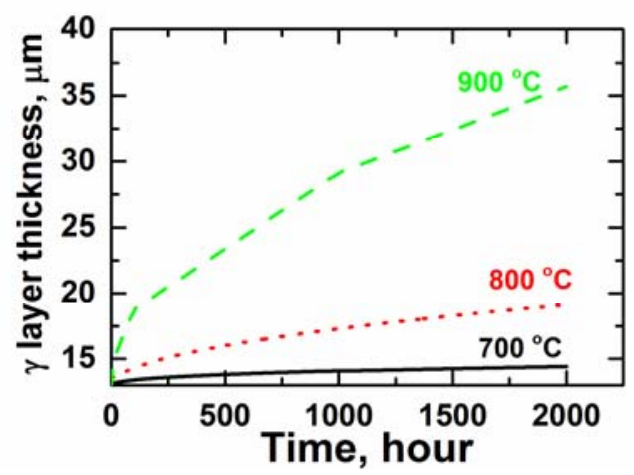

525 Figure 8. (a) Calculated Ni diffusion distance and (b) thickness of the $\gamma$ layer in the

526 diffusion couple of $\mathrm{Ni}-\mathrm{Fe}_{0.76} \mathrm{Cr}_{0.24}$ heat treated at $700-900{ }^{\circ} \mathrm{C}$ for periods up to $2000 \mathrm{~h}$.

527 The initial thickness was $13 \mu \mathrm{m}$ and $150 \mu \mathrm{m}$ for the $\mathrm{Ni}$ and $\mathrm{Fe}_{0.76} \mathrm{Cr}_{0.24}$ layers,

528 respectively. The Ni diffusion distance is defined as the distance from the initial $\gamma / \alpha$

529 interface at $0 \mathrm{~h}$ (i.e. Distance $=13 \mu \mathrm{m}$ in Figure 1 ) to the position where the Ni content

530 reaches below 0.5 wt.\%. Only bulk diffusion was considered here. 


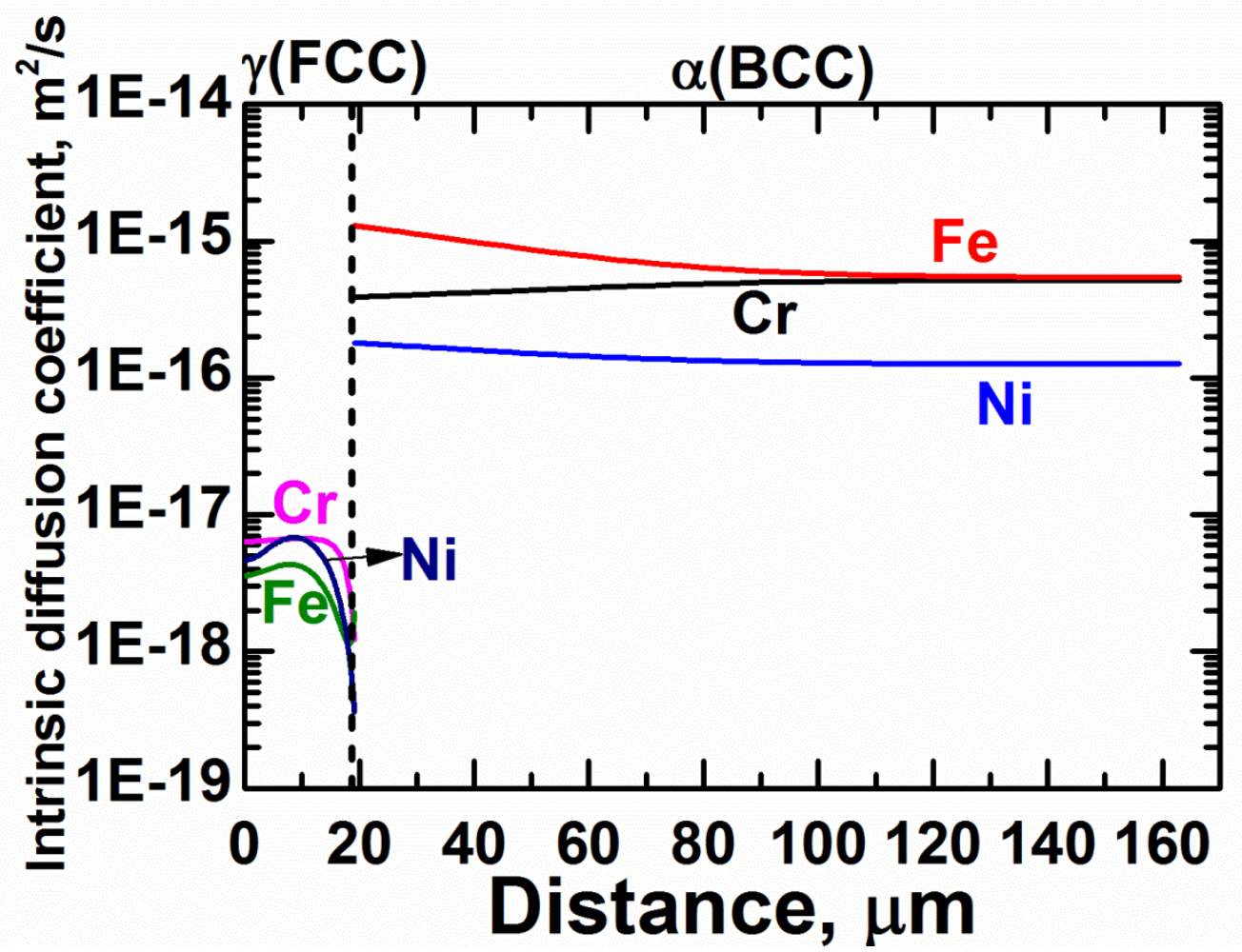

534 Figure 9. Intrinsic diffusion coefficients of $\mathrm{Cr}, \mathrm{Ni}$ and $\mathrm{Fe}$ in $\alpha$ and $\gamma$ phases along the

535 diffusion couple of $\mathrm{Ni}-\mathrm{Fe}_{0.76} \mathrm{Cr}_{0.24}$ heat treated at $800{ }^{\circ} \mathrm{C}$ at Time $=2000 \mathrm{~h}$. Only bulk

536 diffusion was considered here.

537

538 

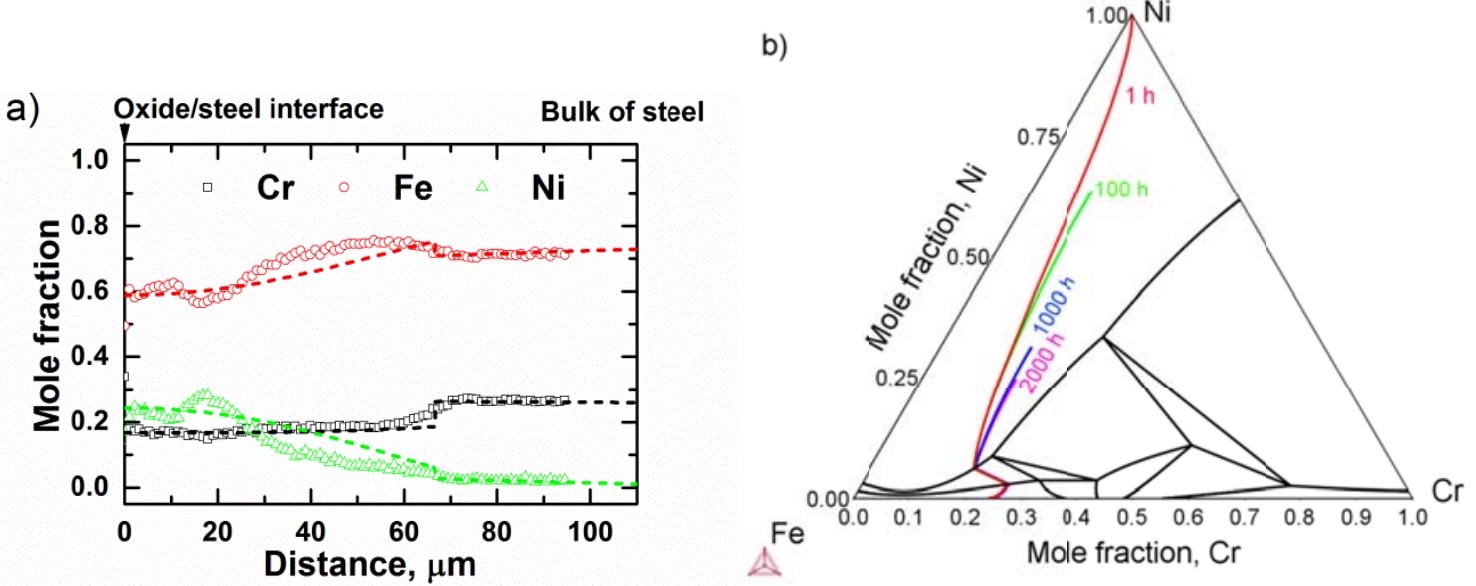

547 Figure 10. (a) Left: Simulated composition profiles (in mole fraction) along the diffusion

548 couple of $\mathrm{Ni}-\mathrm{Fe}_{0.76} \mathrm{Cr}_{0.24}$ heat treated at $800{ }^{\circ} \mathrm{C}$ for periods up to $2000 \mathrm{~h}$. The initial

549 thickness was $13 \mu \mathrm{m}$ and $150 \mu \mathrm{m}$ for the $\mathrm{Ni}$ and $\mathrm{Fe}_{0.76} \mathrm{Cr}_{0.24}$ layers, respectively. Both

550 bulk and grain boundary diffusion are considered. The experimental data points are from

551 the present work (Figure 2c). Mn was excluded in calculating mole fraction; (b) Right:

552 diffusion path at $1 \mathrm{~h}$ (red), $100 \mathrm{~h}$ (green), $1000 \mathrm{~h}$ (blue), $2000 \mathrm{~h}$ (pink) super-imposed

553 onto the Fe-Cr-Ni phase diagram at $800{ }^{\circ} \mathrm{C}$.

548

549 


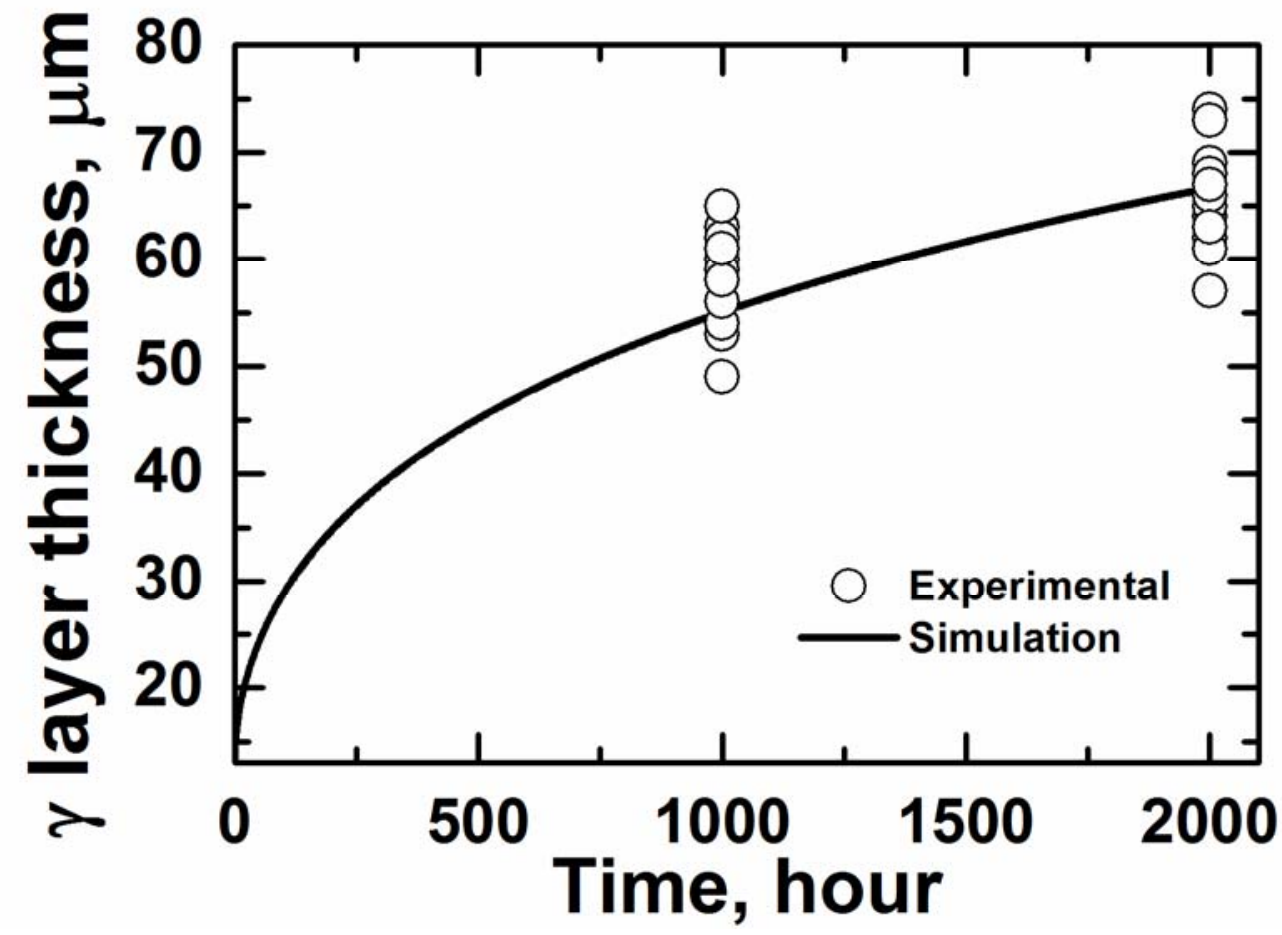

550 Figure 11. Thickness of the $\gamma$ layer in the diffusion couple of $\mathrm{Ni}-\mathrm{Fe}_{0.76} \mathrm{Cr}_{0.24}$ heat treated

551 at $800{ }^{\circ} \mathrm{C}$ for periods up to $2000 \mathrm{~h}$. The initial thickness was $13 \mu \mathrm{m}$ and $150 \mu \mathrm{m}$ for the

$552 \mathrm{Ni}$ and $\mathrm{Fe}_{0.76} \mathrm{Cr}_{0.24}$ layers, respectively. The experimental values were obtained from SEM

553 image analysis, where the thickness of Layers $1+2+3$ was measured at 20-30 different

554 locations.

555

556

557

558 